\title{
Phytopathology"
}

\section{Transmission of Begomoviruses and Other Whitefly-Borne Viruses: Dependence on the Vector Species}

\author{
Elvira Fiallo-Olivé, ${ }^{1}$ Li-Long Pan, ${ }^{2}$ Shu-Sheng Liu, ${ }^{2, \dagger}$ and Jesús Navas-Castillo, ${ }^{1, \dagger}$
}

\begin{abstract}
${ }^{1}$ Instituto de Hortofruticultura Subtropical y Mediterránea "La Mayora", Consejo Superior de Investigaciones Científicas-Universidad de Málaga (IHSM-CSIC-UMA), 29750 Algarrobo-Costa, Málaga, Spain

${ }^{2}$ Ministry of Agriculture Key Lab of Molecular Biology of Crop Pathogens and Insects, Institute of Insect Sciences, Zhejiang University, 310058 Hangzhou, China

Accepted for publication 17 September 2019.
\end{abstract}

\begin{abstract}
Most plant viruses require a biological vector to spread from plant to plant in nature. Among biological vectors for plant viruses, hemipteroid insects are the most common, including phloem-feeding aphids, whiteflies, mealybugs, planthoppers, and leafhoppers. A majority of the emerging diseases challenging agriculture worldwide are insect borne, with those transmitted by whiteflies (Hemiptera: Aleyrodidae) topping the list. Most damaging whitefly-transmitted viruses include begomoviruses (Geminiviridae), criniviruses (Closteroviridae), and torradoviruses (Secoviridae). Among the whitefly vectors, Bemisia tabaci, now recognized as a complex of cryptic species, is the most harmful in terms of virus transmission. Here, we review the available information on the differential transmission efficiency of begomoviruses and other whitefly-borne viruses by different species of whiteflies, including the cryptic species of the B. tabaci complex. In addition, we summarize the factors affecting transmission of viruses by whiteflies and point out some future research prospects.
\end{abstract}

Keywords: begomoviruses, Bemisia tabaci, criniviruses, cryptic species, differential transmission, plant viruses, torradoviruses, Trialeurodes vaporariorum, virology, whiteflies

Plant viruses usually require a biological vector for horizontal transmission in nature (i.e., for plant-to-plant spread). Among biological vectors for plant viruses, insects are the most common and important. Plant viruses are transmitted by their insect vectors in either nonpersistent, semipersistent, or persistent mode, depending on the minimum time period required for acquisition and maximum duration of retention of the virions (Nault 1997; $\mathrm{Ng}$ and Falk 2006) (Table 1). The minimum acquisition access period varies from seconds to minutes for nonpersistent, from minutes to hours for semipersistent, and hours for persistent viruses. Nonpersistent and semipersistent viruses are typically stylet borne and foregut borne, respectively. Persistent viruses move from the foregut to

${ }^{\dagger}$ Corresponding authors: J. Navas-Castillo; jnavas@eelm.csic.es; and S.-S. Liu; shshliu@zju.edu.cn

Funding: Research in the Navas-Castillo group has been funded by the Ministerio de Economía, Industria y Competitividad (Spain) and the European Regional Development Fund through grant AGL2016-75819-C2-2-R.

E. Fiallo-Olivé and L.-L. Pan contributed equally to this work.

The authors declare no conflict of interest.

(C) 2020 The American Phytopathological Society the mid- and hindgut, from where they are transported to the hemolymph and further to the salivary glands to be released into plant tissues. Persistent viruses do (propagative) or do not (circulative) replicate in the insect vector. Additional details on transmission characteristics of plant viruses by insects are shown in Table 1.

Hemipteroid insects are the most common vectors for plant viruses, including phloem-feeding aphids, whiteflies, planthoppers, and leafhoppers. It should be stressed that, among the virus diseases that have emerged in the past two decades, most are caused by viruses transmitted by whiteflies (Hemiptera: Aleyrodidae) (Navas-Castillo et al. 2011) (Table 2). They include begomoviruses (Geminiviridae), criniviruses (Closteroviridae), torradoviruses (Secoviridae), and ipomoviruses (Potyviridae). In the genus Carlavirus (Betaflexiviridae), only cowpea mild mottle virus (CPMMV) is transmitted by whiteflies (Zanardo and Carvalho 2017). Another unexpected case has been reported recently: the polerovirus (Luteoviridae) pepper whitefly-borne vein yellows virus (PeWBVYV) has been shown to be transmitted by whiteflies, an exception in the whole family Luteoviridae, whose members are typically transmitted by aphids (Ghosh et al. 2019).

Whiteflies are small insects, approximately 1 to $3 \mathrm{~mm}$ long, and named as such because the wings and bodies of the adults are covered with a powdery or white wax. They are mainly tropical insects but are found in all warmer parts of the world and in 
2015; Wang et al. 2016). In addition to B. tabaci, two species of whiteflies have been reported to vector begomoviruses, although these results have not been repeated by others. These unexpected results include transmission of TYLCV by T. ricini in Egypt (Idriss et al. 1997) and tomato leaf curl New Delhi virus by $T$. vaporariorum in India (Sangeetha et al. 2018).

Begomoviruses constitute a group of plant viruses which have emerged in recent decades as serious threats to the production of many vegetable, root, and fiber crops in the tropical, subtropical, and temperate regions of the world (Navas-Castillo et al. 2011). Their increasing significance in modern agriculture has renewed scientific interest in the study of begomovirus biology, including transmission by whitefly vectors. Although, thus far, only a limited number of detailed studies concerning whitefly transmission of begomoviruses are available, some patterns start to emerge, including differential transmission depending on the $B$. tabaci species.

In one of the earliest attempt to analyze the differential transmission of begomoviruses, Bedford et al. (1994) found that whiteflies of what we now consider species of the B. tabaci complex-at that moment, biotypes - exhibited differential capacities to transmit a number of begomoviruses. Later, Sánchez-Campos et al. (1999) found that both TYLCV and tomato yellow leaf curl Sardinia virus (TYLCSV) were transmitted with differential efficiencies by whiteflies of the species Middle East-Asia Minor 1 (MEAM1) and Mediterranean (MED), formerly biotypes B and Q, respectively. MED was shown to be a better transmitter than MEAM1, an observation that was supported by the results obtained later by quantifying the relative amount of both begomoviruses in tomato test plants (Ning et al. 2015).

Since then, a series of investigations have been undertaken, and the results support the idea that many begomoviruses are differentially transmitted by different species of the $B$. tabaci complex. Thus far, TYLCV, Chino del tomate virus, tomato yellow leaf curl China virus (TYLCCNV), tomato leaf curl Bangalore virus (ToLCBaV), papaya leaf curl China virus (PaLCuCNV), tomato leaf curl Taiwan virus (ToLCTWV), tomato yellow leaf curl Thailand virus (TYLCTHV), cotton leaf curl Multan virus (CLCuMuV), euphorbia yellow mosaic virus (EuMV), bhendi yellow vein mosaic virus, and tobacco curly shoot virus (TbCSV) have been found to be transmitted by whiteflies of different B. tabaci species with different efficiencies (Chen et al.

TABLE 3

Whiteflies known to vector plant viruses ${ }^{a}$

\begin{tabular}{|c|c|c|}
\hline Whitefly species & Abbreviation & Biotypeb \\
\hline Aleurodicus dispersus & $\ldots$ & $\ldots$ \\
\hline Bemisia afer sensu lato & $\ldots$ & $\ldots$ \\
\hline B. tabaci Asia 1 & $\ldots$ & $\mathrm{H}$ \\
\hline B. tabaci Asia II 1 & $\ldots$ & $\mathrm{ZHJ} 2$ \\
\hline B. tabaci Asia II 3 & $\ldots$ & ZHJ1 \\
\hline B. tabaci Asia II 7 & $\ldots$ & $\mathrm{Cv}$ \\
\hline B. tabaci Mediterranean & MED & Q \\
\hline B. tabaci Middle East-Asia Minor 1 & MEAM1 & $\mathrm{B}$ \\
\hline B. tabaci New World & NW & A \\
\hline B. tabaci New World 2 & NW2 & $\ldots$ \\
\hline Trialeurodes abutiloneus & $\ldots$ & $\ldots$ \\
\hline T. ricini & $\ldots$ & $\ldots$ \\
\hline T. vaporariorum & $\ldots$ & $\ldots$ \\
\hline \multicolumn{3}{|c|}{$\begin{array}{l}\text { a Although many other species of the } B \text {. tabaci complex may vector } \\
\text { plant viruses, only those discussed in this review are included here. } \\
\text { b The most common biotype, following former classification, is } \\
\text { indicated. }\end{array}$} \\
\hline
\end{tabular}

2016; Chowda-Reddy et al. 2012; De Marchi et al. 2017; Guo et al. 2015; Idris et al. 2001; Li et al. 2010; Jiu et al. 2006; Pan et al. 2018a,b; Venkataravanappa et al. 2017; Wei et al. 2014; Weng et al. 2015) (Table 4).

Also, some begomoviruses are reported to be transmitted by whiteflies of different species with similar efficiencies. For example, in contrast to previous results (Ning et al. 2015; Sánchez-Campos et al. 1999), TYLCV was transmitted by MEAM1 and MED with the same efficiency in in a later study (Wei et al. 2014). In addition, De Marchi et al. (2017) did not find differences in transmission of bean golden mosaic virus (BGMV) and tomato severe rugose virus by MEAM1 and New World 2 (NW2) whiteflies. However, it should be mentioned that, in the case of TYLCV (Wei et al. 2014) and BGMV (De Marchi et al. 2017), the transmission efficiencies were found to

TABLE 4

Specificity of begomovirus transmission by different species of the Bemisia tabaci complex

\begin{tabular}{|c|c|c|}
\hline Begomovirus $^{a}$ & B. tabaci species ${ }^{b}$ & Reference \\
\hline BGMV & $\mathrm{NW} 2$ = MEAM1 & $\begin{array}{l}\text { De Marchi } \\
\text { et al. } 2017 \\
\end{array}$ \\
\hline BYVMV & MEAM1 > Asia 1 & $\begin{array}{l}\text { Venkataravanappa } \\
\text { et al. } 2017 \\
\end{array}$ \\
\hline CdTV & NW > MEAM1 & Idris et al. 2001 \\
\hline \multirow[t]{2}{*}{ CLCuMuV } & $\begin{array}{l}\text { Asia } \| 1 \text { > Asia } \| \text { > } \\
\text { MEAM1 }=0\end{array}$ & Chen et al. 2016 \\
\hline & $\begin{array}{r}\text { Asia II } 1>\text { MED } \approx \\
\text { Asia } 1 \approx \text { MEAM1 }\end{array}$ & Pan et al. 2018b \\
\hline EuMV & NW2 > MEAM1 & $\begin{array}{l}\text { De Marchi } \\
\text { et al. } 2017 \\
\end{array}$ \\
\hline PaLCuCNV & $\begin{array}{l}\text { MEAM1 > Asia II } 7> \\
\text { MED > Asia } 1\end{array}$ & Guo et al. 2015 \\
\hline \multirow[t]{2}{*}{ TbCSV } & Asia II $3 \approx$ MEAM1 & Jiu et al. 2006 \\
\hline & $\begin{array}{c}\text { Asia II } 1>\text { Asia } 1> \\
\text { MED > MEAM1 }\end{array}$ & Pan et al. 2018a \\
\hline ToLCBaV & MEAM1 > Asia 1 & $\begin{array}{l}\text { Chowda-Reddy } \\
\text { et al. } 2012\end{array}$ \\
\hline TYLCTHV & MEAM1 > MED & Weng et al. 2015 \\
\hline TOLCTWV & MEAM1 > MED & Weng et al. 2015 \\
\hline ToSRV & NW2 = MEAM1 & $\begin{array}{l}\text { De Marchi } \\
\text { et al. } 2017\end{array}$ \\
\hline \multirow[t]{2}{*}{ TYLCCNV } & MEAM1 $\approx$ Asia II 3 & Jiu et al. 2006 \\
\hline & MEAM1 $>$ MED $=0$ & Wei et al. 2014 \\
\hline TYLCSV & MED > MEAM1 & $\begin{array}{l}\text { Sánchez-Campos } \\
\text { et al. } 1999\end{array}$ \\
\hline \multirow[t]{3}{*}{ TYLCV } & MED > MEAM1 & $\begin{array}{l}\text { Sánchez-Campos } \\
\text { et al. } 1999\end{array}$ \\
\hline & $\begin{array}{l}\text { MED > MEAM1 > } \\
\text { Asia II } 1\end{array}$ & Li et al. 2010 \\
\hline & MED = MEAM1 & Wei et al. 2014 \\
\hline
\end{tabular}

Bean golden mosaic virus (BGMV), bhendi yellow vein mosaic virus (BYVMV), chino del tomate virus (CdTV), cotton leaf curl Multan virus (CLCUMuV), euphorbia yellow mosaic virus (EuMV), papaya leaf curl China virus (PaLCuCNV), tobacco curly shoot virus (TbCSV), tomato leaf curl Bangalore virus (ToLCBaV), tomato yellow leaf curl Thailand virus (TYLCTHV), tomato leaf curl Taiwan virus (ToLCTWV), tomato severe rugose virus (ToSRV), tomato yellow leaf curl China virus (TYLCCNV), tomato yellow leaf curl Sardinia virus (TYLCSV), tomato yellow leaf curl virus (TYLCV).

b B. tabaci New World 2 (NW2), B. tabaci Middle East-Asia Minor 1 (MEAM1), B. tabaci New World (NW), and B. tabaci Mediterranean (MED). 
be $100 \%$, suggesting that the experimental setup used might not be suitable to reveal subtle differences. This stresses the importance of setting experimental conditions within certain ranges for which variation in transmission efficiency could be observed.

From the side of virus, several examples exist of different begomoviruses transmitted differentially by a single $B$. tabaci species. Bedford et al. (1994) presented the first evidence showing that different begomoviruses were transmitted by a population of MEAM1 with varied efficiencies. Examples of this phenomenon include differential transmission by MEAM1 (TYLCV > TYLCSV and TYLCTHV > ToLCTWV) and MED (TYLCV > TYLCSV and TYLCV > TYLCCNV = 0) (Sánchez-Campos et al.1999; Wei et al. 2014; Weng et al. 2015).

\section{CRINIVIRUSES}

The genus Crinivirus is one of the four genera in the family Closteroviridae (Adams et al. 2014; Martelli et al. 2012). This genus comprises flexuous viruses with segmented (bipartite or tripartite) linear positive-sense single-stranded RNA genomes. Criniviruses are unique among the closterovirids in that they are transmitted by whiteflies belonging to the genera Bemisia or Trialeurodes in a semipersistent manner, a noncirculative mode of transmission poorly understood ( $\mathrm{Ng}$ and Falk 2006). Studies with lettuce infectious yellows virus (LIYV) have revealed that the virions are retained in the anterior foregut or cibarium of a vector whitefly (B. tabaci New World $[\mathrm{NW}]$ ) but not within nonvector whiteflies (B. tabaci MEAM1) (Chen et al. 2011).

B. tabaci-borne criniviruses are usually transmitted by multiple species of the complex, LIYV being an exception that is transmitted with high efficiency by NW but not by MEAM1 (Wisler et al. 1998a). In contrast, another crinivirus infecting lettuce, lettuce chlorosis virus (LCV), is transmitted with similar efficiencies by both whitefly species. It has been suggested that changes in whitefly populations in the southwestern United States led to the displacement of LIYV by LCV (see "Epidemiological Implications" below).

Tomato chlorosis virus (ToCV), a typical emergent virus still expanding its geographical and host ranges (Fiallo-Olivé and Navas-Castillo 2019), is transmitted semipersistently by at least six whitefly species: MEAM1, MED, NW, and NW2 species of the B. tabaci complex, T. vaporariorum, and T. abutiloneus (De Marchi et al. 2017; Navas-Castillo et al. 2000; Wisler et al. 1998a,b). The transmission efficiencies differ among the whitefly species, following the order MEAM $1 \approx T$. abutiloneus $>\mathrm{NW}>T$. vaporariorum and MEAM1 > NW2 in the experiments carried out by Wintermantel and Wisler (2006) and De Marchi et al. (2017) with Physalis wrightii in the United States and tomato in Brazil, respectively. On the other hand, experiments performed in China quantifying ToCV acquisition and retention time by the vector, as well as virus accumulation in inoculated tomato plants, provide indirect evidence that the transmission efficiency by MED is higher than by MEAM1 (Shi et al. 2018).

Cucurbit yellow stunting disorder virus (CYSDV) has been experimentally transmitted by B. tabaci MEAM1, MED and NW. Transmission rates were similar for MEAM1 and MED (Berdiales et al. 1999) and higher for MEAM1 than for NW (Wisler et al. 1998a) in experiments carried out in Spain and United States, respectively.

Sweet potato chlorotic stunt virus (SPCSV) alone causes only mild symptoms in sweet potato cultivars (Valverde et al. 2004). However, it causes a severe disease of sweet potato, the sweet potato viral disease, when present in mixed infections with sweet potato feathery mottle virus (SPFMV), a typical potyvirus transmitted by aphids (Cohen et al. 1992; Gibson et al. 1998; Karyeija et al. 2000). Transmission studies with SPCSV from sweet potato coinfected with SPFMV to Ipomoea nil showed a higher efficiency with MEAM1 than with T. abutiloneus (Sim et al. 2000). On the other hand, the transmission efficiency of SPCSV was shown to be similar using MEAM1 or B. afer sensu lato regardless of whether it was acquired from plants singly infected or doubly infected with SPCSV and SPFMV (Gamarra et al. 2010). Although B. tabaci MED has also been shown to transmit SPCSV (Valverde et al. 2003), no comparison experiments have been carried out with other whitefly vectors.

\section{TORRADOVIRUSES}

The genus Torradovirus is one of the five genera in the family Secoviridae (Thompson et al. 2017). Torradoviruses are spherical viruses with bipartite linear positive-sense single-stranded RNA genomes. Isolates of Tomato torrado virus (ToTV), the type species of the genus, were firstly shown to be transmitted by whiteflies; a Polish isolate by $T$. vaporariorum (Pospieszny et al. 2007) and a Spanish isolate by T. vaporariorum and B. tabaci MED (Amari et al. 2008). ToTV, tomato marchitez virus (ToMarV) and tomato chocolàte virus ( $\mathrm{ToChV}$ ) have been shown to be transmitted in a semipersistent manner by B. tabaci MEAM1, T. vaporariorum and T. abutiloneus (Verbeek et al. 2014). The three viruses were found in the whitefly stylet but not in the head where the pharynx of the foregut is located, indicating a stylet-borne mode of transmission.

Transmission efficiency of torradoviruses by the different whitefly species seems to vary between virus isolates. Thus, the transmission rates of ToTV (PRI-ToTV0301 from Spain) and ToMarV (T592 from Mexico) using Nicotiana glutinosa as source plant and $N$. hesperis as receptor plant were identical with the three above-mentioned whiteflies whereas those of ToMarV (PRI-TmarV0601 from Mexico) and ToChV (ToChVV-G01 from Guatemala) were identical with B. tabaci MEAM1 and T. vaporariorum and higher than with T. abutiloneus (Verbeek et al. 2014). Although these results suggest some level of differential transmission, it should be mentioned that only four plants were inoculated per virus isolate-whitefly species combination. The transmission rate by different whiteflies has also been studied for tomato necrotic dwarf virus (ToNDV) in California. ToNDV has been shown to be transmitted by $B$. tabaci MEAM and NW, T. vaporariorum and T. abutiloneus (Larsen et al. 1984; Wintermantel et al. 2018), and comparative assays have shown that T. abutiloneus is a slightly better vector than T. vaporariorum (Wintermantel et al. 2018).

Surprisingly, recently it has been reported that two torradoviruses belonging to a phylogenetic subgroup within the genus, carrot torrado virus and lettuce necrotic leaf curl virus, are transmitted by aphids (Rozado-Aguirre et al. 2016; Verbeek et al. 2017).

\section{IPOMOVIRUSES}

The genus Ipomovirus is one of the 10 genera in the family Potyviridae (King et al. 2018; Wylie et al. 2017). This genus comprises filamentous viruses with monopartite linear positivesense single-stranded RNA genomes that infect important crops including cucurbits (cucumber vein yellowing virus and squash vein yellowing virus), tomato (tomato mild mottle virus), sweet potato (sweet potato mild mottle virus) and cassava (cassava brown streak virus [CBSV] and Ugandan cassava brown streak virus).

Ipomoviruses are the only potivirids transmitted by the whitefly B. tabaci, in a semipersistent manner (Navas-Castillo et al. 2011). However, there are two reports from Kenya showing that CBSV is transmitted, in addition to B. tabaci (Maruthi et al. 2005), by Aleurodicus dispersus (Mware et al. 2009; Njoroge et al. 2017) and T. vaporariorum (Njoroge et al. 2017). Transmission efficiency of CBSV by $T$. vaporariorum was similar to that obtained with B. tabaci, and higher than with A. dispersus.

\section{CARLAVIRUSES}

The genus Carlavirus is one of the three genera in the subfamily Quinvirinae of the family Betaflexiviridae (Adams et al. 2016). This 
genus comprises filamentous viruses with monopartite linear positivesense single-stranded RNA genomes. With one exception (CPMMV), carlaviruses are transmitted naturally by aphids (Adams et al. 2012). CPMMV is however transmitted by the whitely B. tabaci in a nonpersistent manner (Zanardo and Carvalho 2017).

In transmission experiments using common bean as source and receptor plants and 15 adults per plant confined in leaf clip cages, CPMMV was found to be transmitted more efficiently by $B$. tabaci MEAM1 (100\%) than by B. tabaci NW2 (40\%) (De Marchi et al. 2017).

\section{FACTORS AFFECTING DIFFERENTIAL TRANSIMISSION}

Whitefly factors. Most of the information about possible factors intervening in the differential transmission of plant viruses by different whitefly species come from studies on begomovirus transmission.

The geographical origin of both begomovirus and $B$. tabaci populations has been, for example, analyzed on this regard. Thus, McGrath and Harrison (1995) brought forward the first evidence showing that the transmission efficiencies of begomoviruses by whiteflies were higher when the virus and vector used for transmission were from the same geographic origin, either Western Africa or the India Subcontinent, than those whose origin did not overlap. Later, NW whiteflies (native to the Americas) were shown to be better transmitters for a New World begomovirus than MEAM1 (native to the Middle East and Asia Minor regions) (Idris et al. 2001). A similar conclusion was reached when studying cassava mosaic begomoviruses and $B$. tabaci populations from Africa and the India Subcontinent (Maruthi et al. 2002). This conclusion was further supported by reports on many viruses, e.g., TYLCV, EuMV, CLCuMuV and TbCSV (Chen et al. 2016; De Marchi et al. 2017; Li et al. 2010; Pan et al. 2018a, b). This suggests that a coevolution process has taken place between viruses and their vectors. However, there are numerous exceptions to this; some begomoviruses such as ToLCBaV, PaLCuCNV and TYLCCNV, were found to be transmitted more efficiently by the invasive MEAM1 than by indigenous whiteflies (Chowda-Reddy et al. 2012; Guo et al. 2015; Jiu et al. 2006).

In the process of persistent transmission of begomoviruses, the retention by the whitefly, rather than ingestion from the plant, seems to be critical (Czosnek et al. 2017; Guo et al. 2015, 2018; Pan et al. 2018a, b). In many cases, a strong positive correlation between quantity of virus retained by whiteflies and virus transmission efficiency is found. For example, when working with PaLCuCNV, higher quantity of virus in MEAM1 was found when compared with MED, which mirrored the pattern of variation of transmission efficiency (Guo et al. 2015, 2018). Also, TYLCCNV, transmitted by MEAM1 with higher efficiency than by Asia II 3, reaches detectable accumulation level in more MEAM1 whiteflies than in Asia II 3 after a certain acquisition access period (Jiu et al. 2006). It should also be noted that in a few cases the pattern of virus retention, presented as the percentage of viruliferous whiteflies, is not in accordance with the pattern of virus transmission efficiency. For example, although similar percentage of MEAM1 and MED whiteflies were found to become viruliferous after exposure to TYLCV or TYLCSV, differential transmission by whiteflies of the two species was found for both viruses (Sánchez-Campos et al. 1999).

For begomoviruses to achieve successful transmission, they need to cross the midgut wall to reach the hemolymph and then accumulate in the primary salivary glands, from where they are secreted in the saliva to infect new plants (Czosnek et al. 2017). Therefore, variation of virus movement, namely the process of virus transport across midgut wall and virus passage through primary salivary glands, in different begomovirus-whitefly combinations, has profound influence on shaping differential transmission.
Indeed, the pattern of differential capacity of certain viruses to cross the midgut of whiteflies of different species, as reflected by the quantity of virus in hemolymph, clearly mirrors the pattern of differential transmission, such as in the cases of PaLCuCNV, CLCuMuV and TbCSV (Guo et al. 2015, 2018; Pan et al. 2018a, b). The same is true when it comes to the process of virus passage through primary salivary glands. For example, the incapacity of TYLCCNV to accumulate in the cells around the secretory region of primary salivary glands of MED whiteflies resulted in no virus passage into saliva, and thus no virus transmission (Wei et al. 2014). Further, virus movement scenario in certain begomovirus-whitefly combination is always found to be in line with that of virus retention, which suggests when more viruses are retained, more viruses get to cross the midgut wall and passage through primary salivary glands (Guo et al. 2015, 2018; Pan et al. 2018a, b; Wei et al. 2014).

The persistent transmission of begomoviruses by $B$. tabaci involves an additional partner, certain endosymbiotic bacteria. For example, it has been shown that transmission of TYLCV depends on chaperonin GroEL homologs produced by endosymbiotic bacteria, which were proposed to protect the virus from destruction during its passage through the hemolymph (Morin et al. 1999). Moreover, whitefly populations belonging to the same species, with or without a certain endosymbiont species, may vary in their capacity to transmit begomoviruses. Thus, it was found that the transmission efficiency of TYLCV by several MEAM1 and MED whitefly populations collected from Israel was correlated with the presence of Hamiltonella, with its GroEL protein interacting with the virus coat protein, facilitating transmission (Gottlieb et al. 2010). Also, it has been shown that infection by the endosymbiont Rickettsia made MEAM1 whiteflies better transmitters of TYLCV (Kliot et al. 2014). Another example involves Sub-Saharan Africa 1-subgroup 3 (SSA1-SG3) whiteflies with or without the endosymbiotic bacteria Arsenophonus and Rickettsia which were found to vary in acquisition and retention of East African cassava mosaic virus-Uganda variant (EACMV-UG) (Ghosh et al. 2017). However, it should be noted that the whitefly populations used in these studies were derived from different field populations or from different isofemales, not being able to rule out an effect of the genetic identity of the whitefly populations.

Virus factors. As the only structural protein of begomoviruses, the coat protein has been found to be the sole determinant of begomovirus transmission by whiteflies (Harrison et al. 2002; Höfer et al. 1997). With the addition of more experimental evidence, especially that obtained from studies involving coat protein gene replacement, it became clear that variation in coat proteins is responsible for the variation of whitefly transmission among different begomoviruses (Guo et al. 2018; Pan et al. 2018b; Wei et al. 2014). Replacement of the coat protein gene in TYLCV with that of TYLCCNV rendered the TYLCV mutant the same differential transmission pattern as TYLCCNV by whiteflies of two species, and vice versa (Wei et al. 2014). It is interesting to notice in those studies that the regions between two conserved peptides in the coat protein, GCEGPCKVQS and LYMACTHASN, seems to determine their differential transmission patterns by whiteflies (Guo et al. 2018; Pan et al. 2018b; Wei et al. 2014). Another point is that the identity between the coat proteins might be an indicator of similarity between different begomoviruses with regard to the differential whitefly transmission patterns. For example, a high identity between the coat proteins of CLCuMuV and TbCSV was found when phylogenetic analysis was performed, and also a similar pattern of differential transmission by whiteflies of several cryptic species was found for both begomoviruses (Pan et al. 2018a, b).

Regarding whitefly-borne viruses other than begomoviruses, little is known about the possible factors or processes involved in the differential transmission. This is associated with the lack of 
information about the precise mode of semipersistent (or nonpersistent in the case of the carlavirus CPMMV) transmission of these viruses and the molecular factors involved, mainly those from the insect side. An exception is the interesting study carried out with the crinivirus LIYV in which retention in the anterior foregut or cibarium could be the key mechanism for the observed differential transmission between NW (vector) and MEAM1 (nonvector) whiteflies (Chen et al. 2011).

\section{EPIDEMIOLOGICAL IMPLICATIONS}

The differential transmission of plant viruses by whiteflies of different species implies that the combination of virus-whitefly species might exert significant influence on the epidemics in the field. For certain begomoviruses, if the most common whiteflies in the field are able to transmit the virus readily, then epidemics are quiet probable, and the risk of virus epidemic is low when the associated whiteflies fail to or barely transmit the virus, due to the lack of efficient vectors. Thus, for example, the begomovirus PaLCuCNV was always found to be associated with MEAM1 whiteflies, the best transmitter for this virus in the areas where damaging outbreaks were recorded (Guo et al. 2015). Also, the high prevalence of the begomovirus CLCuMuVobserved in Pakistan was associated with the dominance of Asia II 1 whiteflies, which were able to transmit the virus readily (Masood and Briddon. 2018; Pan et al. 2018b). On the contrary, for CLCuMuV in China, although it was firstly found in 2006, no major epidemics have been reported probably due to the fact that the whitefly species most commonly found in China were MEAM1 and MED, both of which barely transmit the virus (Hu et al. 2011; Masood and Briddon 2018; Pan et al. 2018b).

The displacement among different viruses may sometimes result from the change of dominant whitefly species in a given area. In Spain, for example, a progressive displacement of the begomovirus TYLCSV by TYLCV-Is was observed in tomato epidemics (Sánchez-Campos et al. 1999); this was associated with a higher transmission efficiency of TYLCV-Is by B. tabaci MEAM1, which could become predominant over MED in the hot season when the major spread of the disease occurred. A similar situation was reported from Taiwan, where the change of dominant whitefly species from MED to MEAM1 and the differential transmission of the two viruses by MEAM1 were proposed to be responsible for the displacement of ToLCTV by TYLCTHV (Weng et al. 2015).

Another interesting example of epidemiological consequences driven by the introduction of an efficient virus vector raises from the observation that in the last years the numbers of novel begomoviruses have increased substantially in Latin America. One of the most important factors responsible for this increase has been probably the introduction of the MEAM1 species of $B$. tabaci in the late 1980s and its rapid spread (Brown et al. 1995). Although there are reports showing that MEAM1 is less efficient than the original NW species as a vector of New World begomoviruses, several properties of the introduced MEAM1, namely larger population size and broader host range, resulted in the gradual predominance in the regions originally colonized by NW (Morales 2010). This phenomenon is well illustrated by the emergence of a high number of begomoviruses infecting tomato in Brazil (Navas-Castillo et al. 2011), thought to be the result of horizontal transfer of indigenous begomoviruses infecting wild plants by MEAM1, which, unlike NW, colonizes easily solanaceous species (França et al. 1996).

Examples of virus displacement associated with changes in whitefly populations have also been reported for criniviruses. LIYV caused severe losses for a wide range of crops including lettuce, melon and sugar beet in southwestern United States in the 1980s when B. tabaci NW was commonly present (Wisler et al. 1998a). In spite of great efforts toward control, LIYV remained a serious threat to crop production until the early 1990s, when MEAM1 rapidly displaced the NW species over a period of several months. The elimination of NW, an efficient vector of LIYV, led to the rapid disappearance of the virus and the emergence of LCV, a slightly milder crinivirus in the same region. LCV can be transmitted with relatively equal efficiency by both NW and MEAM1 (Wisler et al. 1998a). LCV symptoms on lettuce are essentially identical to those of LIYV, but the virus does not affect the same range of hosts as LIYV (Duffus et al. 1996). Wisler et al. (1998a) proposed that LCV was present at the same time as LIYV, but because of the severity of LIYV, and similar virion structure, it was not identified previous to the decline of LIYV. A similar case was reported from Spain, where CYSDV, transmitted by B. tabaci MEAM1 and MED, displaced beet pseudo-yellows virus (BPYV), transmitted by $T$. vaporariorum (Berdiales et al. 1999). BPYV was reported to occur in greenhousegrown cucurbits in southeastern Spain since the early 1980s but, a decade later, a second crinivirus, CYSDV, was detected. Appearance of CYSDV in the area followed the displacement of $T$. vaporariorum by $B$. tabaci in the greenhouses of southeastern Spain.

\section{CONCLUSIONS AND PROSPECTS}

Although a growing body of literature investigating the differential transmission of viruses by different species of whiteflies is emerging, important gaps in knowledge exist. First, most of the available information comes from studies with begomoviruses and species of the B. tabaci complex. Even in this case, much is to be discovered still in regard to the nature of the insect's factors involved in this phenomenon. Also, the epidemiological consequences of bringing together novel begomovirus-whitefly combinations are unpredictable and would require both a close observation on the virus and insect populations present in each area, and experimental work which would help to predict future outcomes.

More studies should be also carried out to reveal the molecular interactions between viruses and whiteflies, thus contributing to determine the basis for the differential transmission by whitefly species. This is especially needed in the case of semipersistently transmitted viruses, for which there is virtually no information on the insect side of the interaction.

As stated above, the studies looking at the effect of endosymbionts on differential transmission of begomoviruses do not provide clear evidence of it, given that differences due to genetic diversity among whitefly populations cannot be ruled out. Thus, additional work is needed to unequivocally assign a direct effect. The additional level of complexity that the presence of endosymbionts implies on the begomovirus differential transmission studies attains special importance as far as they have been shown to contain different endosymbiont populations which, on the other hand, have been recently revealed to be of greater complexity than previously assumed (Wang et al. 2019).

Another challenging issue has been raised by reports of virus transmission by whiteflies not usually associated with transmission of a particular virus group or even supposed not to be a transmitter at all. They include old reports as well as recently available data of transmission of begomoviruses by $T$. ricini and $T$. vaporariorum (Idriss et al. 1997; Sangeetha et al. 2018), the crinivirus SPCSV by B. afer (Gamarra et al. 2010), and the ipomovirus CBSV by A. dispersus and T. vaporariorum (Mware et al. 2009; Njoroge et al. 2017). It is crucial to confirm these findings by replicating the limited experiments reported, thus discriminating between studies suffering technical problems, exceptional cases, or real novel facts which could challenge our currently established knowledge.

A more perplexing observation is the transmission of a polerovirus (genus Polerovirus, family Luteoviridae) by B. tabaci MEAM1, recently reported for PeWBVYV in Israel (Ghosh et al. 2019). PeWBVYV is closely related to members of the pepper vein yellows 
virus complex (Fiallo-Olivé et al. 2018) which, as with the rest of poleroviruses and luteovirids in general, are considered to be exclusively transmitted in nature by aphids (Domier 2012). It remains to be determined whether species of $B$. tabaci other than MEAM1 are able to transmit this virus and whether whitefly transmission is a characteristic unique to PeWBVYV or could be common to other poleroviruses.

\section{LITERATURE CITED}

Adams, M. J., Candresse, T., Hammond, J., Kreuze, J. F., Martelli, G. P., Namba, S., Pearson, M. N., Ryu, K. H., Saldarelli, P., and Yoshikawa, N. 2012. Family Betaflexiviridae. Pages 929-941 in: Virus Taxonomy. Ninth Report of the ICTV. A. M. Q. King, M. J. Adams, E. B. Carstens, and E. J. Lefkowitz, eds. Elsevier/Academic Press, London, U.K.

Adams, M. J., Lefkowitz, E. J., King, A. M. Q., and Carstens, E. B. 2014. Ratification vote on taxonomic proposals to the International Committee on Taxonomy of Viruses (2014). Arch. Virol. 159:2831-2841.

Adams, M. J., Lefkowitz, E. J., King, A. M. Q., Harrach, B., Harrison, R. L., Knowles, N. J., Kropinski, A. M., Krupovic, M., Kuhn, J. H., Mushegian, A. R., Nibert, M., Sabanadzovic, S., Sanfaçon, H., Siddell, S. G., Simmonds, P., Varsani, A., Zerbini, F. M., Gorbalenya, A. E., and Davison, A. J. 2016. Ratification vote on taxonomic proposals to the International Committee on Taxonomy of Viruses (2016). Arch. Virol. 161:2921-2949.

Amari, K., Gonzalez-Ibeas, D., Gómez, P., Sempere, R. N., Sanchez-Pina, M. A., Aranda, M. A., Diaz-Pendon, J. A., Navas-Castillo, J., Moriones, E., Blanca, J., Hernandez-Gallardo, M. D., and Anastasio, G. 2008. Tomato torrado virus is transmitted by Bemisia tabaci and infects pepper and eggplant in addition to tomato. Plant Dis. 92:1139.

Becker, N., Rimbaud, L., Chiroleu, F., Reynaud, B., Thébaud, G., and Lett, J. M. 2015. Rapid accumulation and low degradation: Key parameters of Tomato yellow leaf curl virus persistence in its insect vector Bemisia tabaci. Sci. Rep. 5:17696.

Bedford, I. D., Briddon, R. W., Brown, J. K., Rosell, R. C., and Markham, P. G. 1994. Geminivirus transmission and biological characterisation of Bemisia tabaci (Gennadius) biotypes from different geographic regions. Ann. Appl. Biol. 125:311-325.

Berdiales, B., Bernal, J. J., Sáez, E., Woudt, B., Beitia, F., and Rodríguez-Cerezo, E. 1999. Occurrence of cucurbit yellow stunting disorder virus (CYSDV) and beet pseudo-yellows virus in cucurbit crops in Spain and transmission of CYSDV by two biotypes of Bemisia tabaci. Eur. J. Plant Pathol. 105:211-215.

Brown, J. K., Frohlich, D. R., and Rosell, R. C. 1995. The sweetpotato or silverleaf whiteflies: Biotypes of Bemisia tabaci or a species complex? Annu. Rev. Entomol. 40:511-534.

Chen, A. Y. S., Walker, G. P., Carter, D., and Ng, J. C. K. 2011. A virus capsid component mediates virion retention and transmission by its insect vector. Proc. Natl. Acad. Sci. U.S.A. 108:16777-16782.

Chen, T., Tang, Y. F., Zhao, R., He, Z. F., and Lü, L. H. 2016. Identification of the cryptic species of Bemisia tabaci transmitting Cotton leaf curl Multan virus. J. Plant Prot. 43:91-98 (In Chinese with English abstract).

Chowda-Reddy, R. V., Kirankumar, M., Seal, S. E., Muniyappa, V., Valand, G. B., Govindappa, M. R., and Colvin, J. 2012. Bemisia tabaci phylogenetic groups in India and the relative transmission efficacy of Tomato leaf curl Bangalore virus by an indigenous and an exotic population. J. Integr. Agric. 11:235-248.

Cohen, J., Franck, A., Vetten, H. J., Lesemann, D. E., and Loebenstein, G. 1992. Purification and properties of closterovirus-like particles associated with a whitefly-transmitted disease of sweet potato. Ann. Appl. Biol. 121:257-268.

Czosnek, H., Hariton-Shalev, A., Sobol, I., Gorovits, R., and Ghanim, M. 2017. The incredible journey of begomoviruses in their whitefly vector. Viruses 9:273.

De Barro, P. J., Liu, S. S., Boykin, L. M., and Dinsdale, A. B. 2011. Bemisia tabaci: A statement of species status. Annu. Rev. Entomol. 56:1-19.

De Marchi, B. R., Marubayashi, J. M., Favara, G. M., Yuki, V. A., Watanabe, L. F. M., Barbosa, L. F., Pavan, M. A., and Krause-Sakate, R. 2017. Comparative transmission of five viruses by Bemisia tabaci NW2 and MEAM1. Trop. Plant Pathol. 42:495-499.

Dinsdale, A., Cook, I., Riginos, C., Buckley, Y. M., and De Barro, P. 2010. Refined global analysis of Bemisia tabaci (Hemiptera: Sternorrhyncha: Aleyrodoidea: Aleyrodidae) mitochondrial cytochrome oxidase 1 to identify species level genetic boundaries. Ann. Entomol. Soc. Am. 103:196-208.

Domier, L. L. 2012. Family Luteoviridae. Pages 1045-1053 in: Virus Taxonomy. Ninth Report of the ICTV. A. M. Q. King, M. J. Adams, E. B. Carstens, and E. J. Lefkowitz, eds. Elsevier/Academic Press, London, U.K.

Duffus, J. E., Liu, H. Y., Wisler, G. C., and Li, R. 1996. Lettuce chlorosis virus-A new whitefly-transmitted closterovirus. Eur. J. Plant Pathol. 102: 591-596.
Fiallo-Olivé, E., and Navas-Castillo, J. 2019. Tomato chlorosis virus, an emergent plant virus still expanding its geographical and host ranges. Mol. Plant Pathol. 20:1307-1320.

Fiallo-Olivé, E., Navas-Hermosilla, E., Ferro, C. G., Zerbini, F. M., and Navas-Castillo, J. 2018. Evidence for a complex of emergent poleroviruses affecting pepper worldwide. Arch. Virol. 163:1171-1178.

França, F. H., Villas-Bôas, G. L., and Castelo-Branco, M. 1996. Ocorrência de Bemisia argentifolii Bellows \& Perring (Homoptera: Aleyrodidae) no distrito federal. An. Soc. Entomol. Bras. 25:369-372.

Gamarra, H. A., Fuentes, S., Morales, F. J., Glover, R., Malumphy, C., and Barrer, I. 2010. Bemisia afer sensu lato, a vector of Sweet potato chlorotic stunt virus. Plant Dis. 94:510-514.

Ghosh, S., Bouvaine, S., Richardson, S. C. W., Ghanim, M., and Maruthi, M. N. 2017. Fitness costs associated with infections of secondary endosymbionts in the cassava whitefly species Bemisia tabaci. J. Pest Sci. 91: $17-28$.

Ghosh, S., Kanakala, S., Lebedev, G., Kontsedalov, S., Silverman, D., Alon, T., Mor, N., Sela, N., Luria, N., Dombrovsky, A., Mawassi, M., Haviv, S., Czosnek, H., and Ghanim, M. 2019. Transmission of a new polerovirus infecting pepper by the whitefly Bemisia tabaci. J. Virol. 93:e00488-19.

Gibson, R. W., Mpembe, I., Alicai, T., Carey, E. E., Mwanga, R. O. M., Seal, S. E., and Vetten, H. J. 1998. Symptoms, aetiology and serological analysis of sweet potato virus disease in Uganda. Plant Pathol. 47:95-102.

Gottlieb, Y., Zchori-Fein, E., Mozes-Daube, N., Kontsedalov, S., Skaljac, M., Brumin, M., Sobol, I., Czosnek, H., Vavre, F., Fleury, F., and Ghanim, M. 2010. The transmission efficiency of Tomato yellow leaf curl virus by the whitefly Bemisia tabaci is correlated with the presence of a specific symbiotic bacterium species. J. Virol. 84:9310-9317.

Guo, T., Guo, Q., Cui, X. Y., Liu, Y. Q., Hu, J., and Liu, S. S. 2015. Comparison of transmission of Papaya leaf curl China virus among four cryptic species of the whitefly Bemisia tabaci complex. Sci. Rep. 5:15432.

Guo, T., Zhao, J., Pan, L. L., Geng, L., Lei, T., Wang, X. W., and Liu, S. S. 2018. The level of midgut penetration of two begomoviruses affects their acquisition and transmission by two species of Bemisia tabaci. Virology 515:66-73.

Harrison, B. D., Swanson, M. M., and Fargette, D. 2002. Begomovirus coat protein: Serology, variation and functions. Mol. Plant Pathol. 60:257-271.

Höfer, P., Bedford, I. D., Markham, P. G., Jeske, H., and Frischmuth, T. 1997. Coat protein gene replacement results in whitefly transmission of an insect nontransmissible geminivirus isolate. Virology 236:288-295.

Hu, J., De Barro, P., Zhao, H., Wang, J., Nardi, F., and Liu, S. S. 2011. An extensive field survey combined with a phylogenetic analysis reveals rapid and widespread invasion of two alien whiteflies in China. PLoS One 6:e16061.

Idris, A. M., Smith, S. E., and Brown, J. K. 2001. Ingestion, transmission, and persistence of Chino del tomate virus (CdTV), a New World begomovirus, by Old and New World biotypes of the whitefly vector Bemisia tabaci. Ann. Appl. Biol. 139:145-154.

Idriss, M., Abdallah, N., Aref, N., Haridy, G., and Madkour, M. 1997. Biotypes of the castor bean whitefly Trialeurodes ricini (Misra) (Hom., Aleyrodidae) in Egypt: Biochemical characterization and efficiency of geminivirus transmission. J. Appl. Entomol. 121:501-509.

Jiu, M., Zhou, X. P., and Liu, S. S. 2006. Acquisition and transmission of two begomoviruses by the B and a non-B biotype of Bemisia tabaci from Zhejiang, China. J. Phytopathol. 154:587-591.

Karyeija, R. F., Kreuze, J. F., Gibson, R. W., and Valkonen, J. P. T. 2000. Synergistic interactions of a potyvirus and a phloem-limited crinivirus in sweet potato plants. Virology 269:26-36.

King, A. M. Q., Lefkowitz, E. J., Mushegian, A. R., Adams, M. J., Dutilh, B. E., Gorbalenya, A. E., Harrach, B., Harrison, R. L., Junglen, S., Knowles, N. J., Kropinski, A. M., Krupovic, M., Kuhn, J. H., Nibert, M. L., Rubino, L., Sabanadzovic, S., Sanfaçon, H., Siddell, S. G., Simmonds, P., Varsani, A., Zerbini, F. M., and Davison, A. J. 2018. Changes to taxonomy and the International Code of Virus Classification and Nomenclature ratified by the International Committee on Taxonomy of Viruses (2018). Arch. Virol. 163:2601-2631.

Kliot, A., Cilia, M., Czosnek, H., and Ghanim, M. 2014. Implication of the bacterial endosymbiont Rickettsia spp. in interactions of the whitefly Bemisia tabaci with Tomato yellow leaf curl virus. J. Virol. 88:5652-5660.

Larsen, R. C., Duffus, J. E., and Liu, H. Y. 1984. Tomato necrotic dwarf-A new type of whitefly-transmitted virus. (Abstr.) Phytopathology 74:795.

Lee, W., Park, J., Lee, G. S., Lee, S., and Akimoto, S. I. 2013. Taxonomic status of the Bemisia tabaci complex (Hemiptera: Aleyrodidae) and reassessment of the number of its constituent species. PLoS One 8:e63817.

Li, M., Hu, J., Xu, F. C., and Liu, S. S. 2010. Transmission of Tomato yellow leaf curl virus by two invasive biotypes and a Chinese indigenous biotype of the whitefly Bemisia tabaci. Int. J. Pest Manage. 56:275-280.

Martelli, G. P., Agranovsky, A. A., Bar-Joseph, M., Boscia, M., Candresse, T., Coutts, R. H. A., Dolja, V. V., Hu, J. S., Jelkmann, W., Karasev, A. V., 
Martin, R. R., Minafra, A., Namba, S., and Vetten, H. J. 2012. Family Closteroviridae. Pages 987-1001 in: Virus Taxonomy. Ninth Report of the ICTV. A. M. Q. King, M. J. Adams, E. B. Carstens, and E. J. Lefkowitz, eds. Elsevier/Academic Press, London, U.K.

Martin, J. H. 2004. Whiteflies of Belize (Hemiptera: Aleyrodidae). Part 1 -Introduction and account of the subfamily Aleurodicinae Quaintance \& Baker. Zootaxa 681:1-119.

Maruthi, M. N., Colvin, J., Seal, S., Gibson, G., and Cooper, J. 2002. Coadaptation between cassava mosaic geminiviruses and their local vector populations. Virus Res. 86:71-85.

Maruthi, M. N., Hillocks, R. J., Mtunda, K., Raya, M. D., Muhanna, M., Kozia, H., Rekha, A. R., Colvin, J., and Thresh, J. M. 2005. Transmission of Cassava brown streak virus by Bemisia tabaci (Gennadius). J. Phytopathol. 153:307-312.

Masood, M., and Briddon, R. W. 2018. Transmission of cotton leaf curl disease: Answer to a long-standing question. Virus Genes 54:743-745.

McGrath, P. F., and Harrison, B. D. 1995. Transmission of tomato yellow leaf curl geminiviruses by Bemisia tabaci: Effects of virus isolate and vector biotype. Ann. Appl. Biol. 126:307-316.

Morales, F. J. 2010. Distribution and dissemination of begomoviruses in Latin America and the Caribbean. Pages 283-318 in: Bemisia: Bionomics and Management of a Global Pest. P. A. Stansley and S. E. Naranjo, eds. Springer, Dordrecht, Heidelberg, London, New York.

Morin, S., Ghanim, M., Zeidan, M., Czosnek, H., Verbeek, M., and Heuvel, J. F. 1999. A GroEL homologue from endosymbiotic bacteria of the whitefly Bemisia tabaci is implicated in the circulative transmission of tomato yellow leaf curl virus. Virology 256:75-84.

Mugerwa, H., Seal, S., Wang, H. L., Patel, M. V., Kabaalu, R., Omongo, C. A., Alicai, T., Tairo, F., Ndunguru, J., Sseruwagi, P., and Colvin, J. 2018. African ancestry of New World, Bemisia tabaci-whitefly species. Sci. Rep. 8:2734.

Mware, B., Narla, R., Amata, R., Olubayo, F., Songa, J., Kyamanywa, S., and Ateka, E. M. 2009. Efficiency of cassava brown streak virus transmission by two whitefly species in coastal Kenya. J. Gen. Mol. Virol. 1:40-45.

Nault, L. R. 1997. Arthropod transmission of plant viruses: A new synthesis. Ann. Entomol. Soc. Am. 90:521-541.

Navas-Castillo, J., Camero, R., Bueno, M., and Moriones, E. 2000. Severe yellowing outbreaks in tomato in Spain associated with infections of Tomato chlorosis virus. Plant Dis. 84:835-837.

Navas-Castillo, J., Fiallo-Olivé, E., and Sánchez-Campos, S. 2011. Emerging virus diseases transmitted by whiteflies. Annu. Rev. Phytopathol. 49: 219-248.

Ng, J. C. K., and Falk, B. W. 2006. Virus-vector interactions mediating nonpersistent and semipersistent transmission of plant viruses. Annu. Rev. Phytopathol. 44:183-212.

Ning, W., Shi, X., Liu, B., Pan, H., Wei, W., Zeng, Y., Sun, X., Xie, W., Wang, S., Wu, Q., Peng, Z., and Zhang, Y. 2015. Transmission of Tomato yellow leaf curl virus by Bemisia tabaci as affected by whitefly sex and biotype. Sci. Rep. 5:10744.

Njoroge, M. K., Mutisya, D. L., Miano, D. W., and Kilalo, D. C. 2017. Whitefly species efficiency in transmitting cassava mosaic and brown streak virus diseases. Cogent Biol. 3:1311499.

Pakkianathan, B. C., Kontsedalov, S., Lebedev, G., Mahadav, A., Zeidan, M., Czosnek, H., and Ghanim, M. 2015. Replication of Tomato yellow leaf curl virus in its whitefly vector, Bemisia tabaci. J. Virol. 89:9791-9803.

Pan, L. L., Chen, Q. F., Guo, T., Wang, X. R., Li, P., Wang, X. W., and Liu, S. S. 2018a. Differential efficiency of a begomovirus to cross the midgut of different species of whiteflies results in variation of virus transmission by the vectors. Sci. China Life Sci. 61:1254-1265.

Pan, L. L., Cui, X. Y., Chen, Q. F., Wang, X. W., and Liu, S. S. 2018b. Cotton leaf curl disease: Which whitefly is the vector? Phytopathology 108: $1172-1183$.

Pospieszny, H., Borodynko, N., Obrępalska-Stęplowska, A., and Hasiów, G. 2007. The first report of Tomato torrado virus in Poland. Plant Dis. 91:1364.

Rozado-Aguirre, Z., Adams, I., Collins, L., Fox, A., Dickinson, M., and Boonham, N. 2016. Detection and transmission of Carrot torrado virus, a novel putative member of the Torradovirus genus. J. Virol. Methods 235: 119-124.

Sánchez-Campos, S., Navas-Castillo, J., Camero, R., Soria, C., Díaz, J. A., and Moriones, E. 1999. Displacement of tomato yellow leaf curl virus (TYLCV)-Sr by TYLCV-Is in tomato epidemics in Spain. Phytopathology 89:1038-1043.

Sánchez-Campos, S., Rodríguez-Negrete, E. A., Cruzado, L., Grande-Pérez, A., Bejarano, E. R., Navas-Castillo, J., and Moriones, E. 2016. Tomato yellow leaf curl virus: No evidence for replication in the insect vector Bemisia tabaci. Sci. Rep. 6:30942.
Sangeetha, B., Malathi, V. G., Alice, D., Suganthy, M., and Renukadevi, P. 2018. A distinct seed-transmissible strain of tomato leaf curl New Delhi virus infecting Chayote in India. Virus Res. 258:81-91.

Shi, X., Tang, X., Zhang, X., Zhang, D., Li, F., Yan, F., Zhang, Y., Zhou, X., and Liu, Y. 2018. Transmission efficiency, preference and behavior of Bemisia tabaci MEAM1 and MED under the influence of tomato chlorosis virus. Front. Plant Sci. 8:2271.

Sim, J., Valverde, R. A., and Clark, C. A. 2000. Whitefly transmission of Sweet potato chlorotic stunt virus. Plant Dis. 84:1250.

Thompson, J. R., Dasgupta, I., Fuchs, M., Iwanami, T., Karasev, A. V., Petrzik, K., Sanfaçon, H., Tzanetakis, I., van der Vlugt, R., Wetzel, T., and Yoshikawa, N., and ICTV Report Consortium. 2017. ICTV Virus Taxonomy Profile: Secoviridae. J. Gen. Virol. 98:529-531.

Valverde, R. A., Navas-Castillo, J., Moreira, M. A., and Ramos, A. 2003. Viruses of sweet potato (Ipomoea batatas) in Costa Rica, southern Spain, and the Canary Islands (Abstr.). Page 262 in: Eighth Int. Cong. Plant Pathol. Christchurch, New Zealand.

Valverde, R. A., Sim, J., and Lotrakul, P. 2004. Whitefly transmission of sweet potato viruses. Virus Res. 100:123-128.

Venkataravanappa, V., Kodandaram, M. H., Reddy, C. N. L., Shankarappa, K. S., and Reddy, M. K. 2017. Comparative transmission of Bhendi yellow vein mosaic virus by two cryptic species of the whitefly, Bemisia tabaci (Hemiptera: Aleyrodidae). 3 Biotech 7:331.

Verbeek, M., Dullemans, A. M., and van der Vlugt, R. A. A. 2017. Aphid transmission of Lettuce necrotic leaf curl virus, a member of a tentative new subgroup within the genus Torradovirus. Virus Res. 241:125-130.

Verbeek, M., van Bekkum, P. J., Dullemans, A. M., and van der Vlugt, R. A. A. 2014. Torradoviruses are transmitted in a semi-persistent and stylet-borne manner by three whitefly vectors. Virus Res. 186:55-60.

Walker, P. J., Siddell, S. G., Lefkowitz, E. J., Mushegian, A. R., Dempsey, D. M., Dutilh, B. E., Harrach, B., Harrison, R. L., Hendrickson, R. C., Junglen, S., Knowles, N. J., Kropinski, A. M., Krupovic, M., Kuhn, J. H., Nibert, M., Rubino, L., Sabanadzovic, S., Simmonds, P., Varsani, A., Zerbini, F. M., and Davison, A. J. 2019. Changes to virus taxonomy and the International Code of Virus Classification and Nomenclature ratified by the International Committee on Taxonomy of Viruses (2019). Arch. Virol. 164: 2417-2429.

Wang, H. L., Lei, T., Xia, W. Q., Cameron, S. L., Liu, Y. Q., Zhang, Z., Gowda, M. M. N., De Barro, P., Navas-Castillo, J., Omongo, C. A., Delatte, H., Lee, K. Y., Patel, M. V., Krause-Sakate, R., Ng, J., Wu, S. L., Fiallo-Olivé, E., Liu, S. S., Colvin, J., and Wang, X. W. 2019. Insight into the microbial world of Bemisia tabaci cryptic species complex and its relationships with its host. Sci. Rep. 9:6568.

Wang, L. L., Wang, X. R., Wei, X. M., Huang, H., Wu, J. X., Chen, X. X., Liu, S. S., and Wang, X. W. 2016. The autophagy pathway participates in resistance to tomato yellow leaf curl virus infection in whiteflies. Autophagy $12: 1560-1574$

Wei, J., Zhao, J. J., Zhang, T., Li, F. F., Ghanim, M., Zhou, X. P., Ye, G. Y., Liu, S. S., and Wang, X. W. 2014. Specific cells in the primary salivary glands of the whitefly Bemisia tabaci control retention and transmission of begomoviruses. J. Virol. 88:13460-13468.

Weng, S. H., Tsai, W. S., Kenyon, L., and Tsai, C. W. 2015. Different transmission efficiencies may drive displacement of tomato begomoviruses in the fields in Taiwan. Ann. Appl. Biol. 166:321-330.

Wintermantel, W. M., Hladky, L. L., and Cortez, A. A. 2018. Genome sequence, host range, and whitefly transmission of the torradovirus Tomato necrotic dwarf virus. Acta Hortic. 1207:295-302.

Wintermantel, W. M., and Wisler, G. C. 2006. Vector specificity, host range, and genetic diversity of Tomato chlorosis virus. Plant Dis. 90:814-819.

Wisler, G. C., Duffus, J. E., Liu, H. Y., and Li, R. H. 1998a. Ecology and epidemiology of whitefly-transmitted closteroviruses. Plant Dis. 82: 270-280.

Wisler, G. C., Li, R. H., Liu, H. Y., Lowry, D., and Duffus, J. E. 1998b. Tomato chlorosis virus: A new whitefly-transmitted, phloem-limited bipartite closterovirus of tomato. Phytopathology 88:402-409.

Wylie, S. J., Adams, M., Chalam, C., Kreuze, J., López-Moya, J. J., Ohshima, K., Praveen, S., Rabenstein, F., Stenger, D., Wang, A., and Zerbini, F. M., and ICTV Report Consortium. 2017. ICTV Virus Taxonomy Profile: Potyviridae. J. Gen. Virol. 98:352-354.

Zanardo, L. G., and Carvalho, C. M. 2017. Cowpea mild mottle virus (Carlavirus, Betaflexiviridae): A review. Trop. Plant Pathol. 42:417-430.

Zerbini, F. M., Briddon, R. W., Idris, A., Martin, D. P., Moriones, E., Navas-Castillo, J., Rivera-Bustamante, R., Roumagnac, P., and Varsani, A., and ICTV Report Consortium. 2017. ICTV Virus Taxonomy Profile: Geminiviridae. J. Gen. Virol. 98:131-133. 